
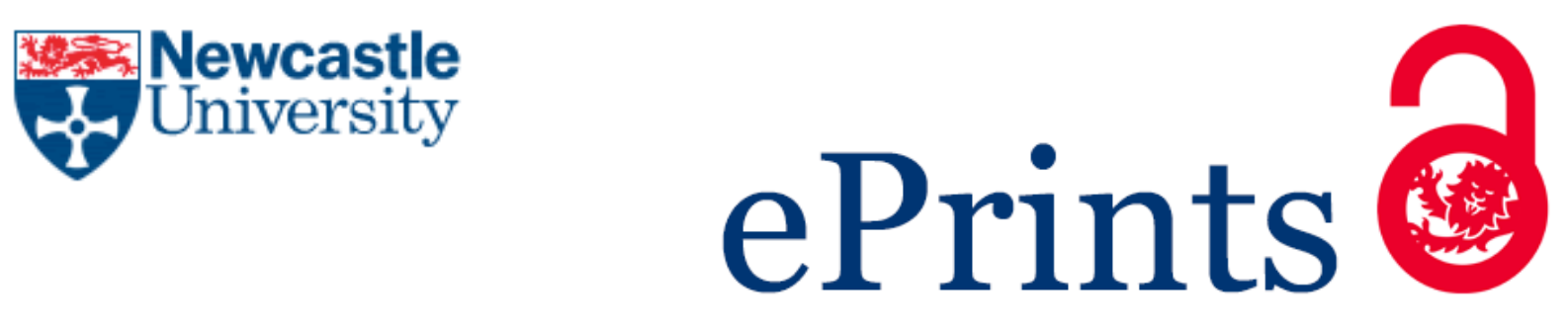

Hewitt L, Pendlebury J.

Local associations and participation in place: change and continuity in the relationship between state and civil society in twentieth-century Britain. Planning Perspectives 2014, 29(1), 25-44.

\title{
Copyright:
}

This is an Accepted Manuscript of an article published by Taylor \& Francis in Planning Perspectives on 25/06/2013, available online: http://dx.doi.org/10.1080/02665433.2013.802655

Date deposited:

$06 / 11 / 2015$

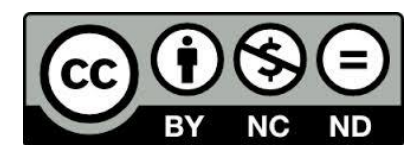

This work is licensed under a

Creative Commons Attribution-NonCommercial-NoDerivatives 4.0 International licence 


\title{
RESEARCH ARTICLE
}

\section{Local associations and participation in place: change and continuity in the relationship between state and civil society during the twentieth century}

\author{
Lucy E. Hewitt* and John Pendlebury \\ Urban Studies, University of Glasgow, UK; School of Architecture and Planning, \\ Newcastle University, UK
}

(Received 2 November 2012; revised April 2013)

\begin{abstract}
This paper uses a review of evidence relating to the history of local civic associations to address the temporally and geographically variable relationship between state and civil society. We focus particularly on the historical development of participative practices, thus also contributing to contemporary debate about the potentials of increased community involvement in place-making. The paper has three primary purposes. First, we assess the role that local associations have played in advancing planning and conservation agendas. Second, we discuss the differing modes of participation that are most visible in the work of local groups. Third, we use a focus on the discussions of participation that took place in the late 1960s, which raised explicit questions about the relations between local state and civil society, to explore a series of problematics relating to the promise and the practice of participation. We argue that in seeking to understand both the past and the present of local associational involvement in place-making and management it is important to recognise that local groups have variable professional and social resources that lead to differences in their ability to engage in local governance. We also argue that this sphere of voluntary activity exhibits continuities with longer term practice, rather than the paradigm shift that is sometimes described in accounts of the development of participation.
\end{abstract}

Key words: state-civil society; voluntary associations; urban governance; planning; conservation; localism.

\footnotetext{
*Corresponding author lucy.hewitt@glasgow.ac.uk
} 


\section{Local associations and participation in place: change and continuity in the relationship between state and civil society during the twentieth century}

Support for participative place-making and management has gathered momentum in the UK over successive recent decades. Current political agendas, most notably an emphasis on localism, signal an apparent interest in the decentralization of decision-making and a renewed emphasis on the importance of Britain's civil society, with new rights and powers promised for local communities and individuals ${ }^{1}$. Following the practical logic of such agendas it would seem reasonable to assume that the involvement of community organizations and residents’ groups will become an increasingly significant element in future place-management processes and, in relation to this paper, specifically in the sphere of town planning and urban conservation. In this context, scrutiny of how state-civil society relationships are formed and negotiated, and how participation works and what it can deliver assumes an important role.

Participation has been a formal and visible part of the planning system in Britain since 1968 and the emergence and growth of this trajectory has often been welcomed as a movement towards democratizing place-based policies. ${ }^{2}$ However, as experience of participative practice has increased, concerns have also emerged. ${ }^{3}$ Furthermore, the dominant theoretical paradigms within academic planning literature - namely those informed by Habermasian ideas and those drawing on Foucauldian theory - have conceptualized participatory practices in markedly contrasting ways, leading some to emphasise the importance of developing understandings that are empirically grounded as well as conceptually alert to questions of power. Brownill and Carpenter, for example, suggest a focus on practice is essential in developing more robust analyses of participation which might be able to accommodate the tensions and ambiguities that emerge through differing examples of participative place-making. ${ }^{4}$ Further, recent examinations of the historical experience of participation have begun to challenge the dominant narrative that depicts a paradigm shift in practice over the 1960s and 1970s. ${ }^{5}$ Instead, as Haumann explains, a locally variable experience of citizens' involvement straddles the decades before and after the mid-century signalling the inadequacy of temporal, as well as theoretical, dichotomies and pointing to the value of continued historical research. ${ }^{6}$

This paper uses a review of evidence relating to local civic associations to address the variable relationship between state and civil society during the twentieth century. We focus 
particularly on the historical development of participative practices, thus also contributing to contemporary debate about the potentials of increased community involvement in place-making. It is not easy to precisely define 'civic associations,' but broadly we include those non-state, voluntary and local associations that aim at improving the quality of the built and natural environment. Typically we are talking about groups that have a clear place focus and, whilst their formation maybe prompted in reaction to a particular development proposal, have a more sustained existence. In Britain civic associations emerged in the latter part of the nineteenth century, but the term has come to be closely associated with those societies affiliated to national civic trusts in England, Scotland and Wales. The exact numbers of local civic groups are difficult to estimate (though some figures are given in later sections of this paper), but such groups form part of the urban associational culture that has been central to British civil society over a period of centuries and which is currently under renewed political scrutiny. ${ }^{7}$ The specific example provided by civic associations offers a number of correlations with contemporary interests in localism, place identity and community engagement. A significant element of the amenity movement, civic associations have maintained a strong focus on the quality of place and the value of local distinctiveness throughout their history. They have also consistently sought opportunities to link civil and political spheres through their involvement in mechanisms such as Conservation Area Advisory Committees. ${ }^{8}$ Further, though there are inevitably specificities in the current discussion that link our arguments particularly to the British context, there are also parallels between our discussion and research concerned with the participatory activities of local associations in relation to the built and natural environment in other national contexts. ${ }^{9}$

The first part of the paper focuses on providing a brief overview of the history of civic groups and a short indication of their core interests and activities in order to contextualize the later discussion. The second part examines the ways groups played a proactive part in developing approaches to town planning and urban conservation during the first half of the twentieth century, underlining the centrality of initiatives that originated with, and in some cases were developed through, civil society. The third section considers the modes of participation most clearly visible in the work of civic groups, particularly focusing on examples of opposition to local development proposals or policies on the one hand, and instances of co-operation and collaboration through local networks and overlapping memberships on the other. Linked to these modes are the roles groups perform in their relationship with the local state. In broad terms, these roles can be categorised as "expert citizen”, whereby local groups add to, or fill a deficiency, in the capacity of the local state, or 
"lay citizen" where the role is constructed more about the group contributing to a wider participative democracy. ${ }^{10}$ Leading from this, the fourth part of the paper focuses on exploring the history of civic groups in relation to the discussions about participation that took place during the late 1960s and which raised explicit questions about the relationship between the local state and civil society. Here we raise and examine a series of problematics concerning the promise and the practice of participation that remain at the centre of contemporary discussion.

An important argument which emerges from the paper is the dangers of overperiodisation. Urban and planning history can often focus on delineating particular phases of activity or emphasising disjunctures between different periods (for example, in the UK, New

Labour, Thatcherism, post-war, pre-war etc). ${ }^{11}$ Whilst there are often good reasons for doing this, periodization can underplay important continuities, specifically in the context of this paper, in the relationships between the state and civil society. Thus, in conclusion we suggest that patterns of urban governance usually seen as characteristic of the Victorian period, which combined a local government and voluntary culture dominated by middle classes, continued well into the twentieth century, that there was no clear disjuncture in practices of participation in the late 1960s and that the history of civic associations offers a useful vantage point on the locally variable experience of participation. Indeed, with the advent of the localism agenda, linked to state austerity measures and the consequent diminution of the capacities of the local state, in the UK we may see local groups reacquiring roles they have historically held more explicitly. Acknowledging the longevity of these structural interrelationships is valuable both for deepening knowledge about contemporary state-civil society relationships and to sharpen the analytical lens through which associational culture and participative practice is viewed.

\section{The growth and activities of local civic associations}

The development of civic associations in the nineteenth century was a local manifestation of a growing interest in landscape, architecture and heritage that resulted from the radical spatial transformations of industrialization and urbanization, and part of a groundswell of associational activity concerned with the quality of the environment. The formation of national campaigning organizations and professional bodies has already drawn attention in histories of modern approaches to shaping space. ${ }^{12}$ Yet, in important respects, 
the less examined proliferation of local voluntarism offers a more extensive indicator of changing sensibilities. Thus, Levine’s research on the growth of antiquarian, archaeological and historical societies provides a strong measure of the spread of interest in the past, while the growth of concern for civic and environmental improvement is evidenced by the proliferation of locally driven associational activities over the mid- and later decades of the nineteenth century. ${ }^{13}$ By the closing years of the nineteenth century, therefore, when civic associations began to emerge in towns and cities throughout the country with a degree of regularity, they did so as part of a well-established British practice of local association aimed at improving the quality of the built and natural environment and were a reflection of the increasingly organized desire of communities to shape the localities in which they lived.

Organization between local groups came later, visible first in the 1920s, when an early conference of civic societies was held, but not consolidated in formal organization until 1938 when the first national body, the Central Council of Civic Societies, was established. ${ }^{14}$ Local associations continued to grow throughout the following years, reaching at least seventy by the late 1940s. ${ }^{15}$ Thus, by the time the Civic Trust ${ }^{16}$ was formed in 1957 the local civic movement was well-established. However, the additional publicity, a changing political context and growing media debate about participation in planning and the value of conservation, combined with continued urban change precipitated a surge of local society formations during the 1960s and 1970s. Research into the movement conducted during the 1970s identified 1,250 local civic societies affiliated to the Civic Trust in $1976 .{ }^{17}$ A more recent account indicates that the numbers of affiliated local societies peaked in the late 1970s at around 1,300 and then began to decline, reaching around 900 societies in the mid-1990s. ${ }^{18}$ These figures are useful as the only longitudinal data on local groups for charting the expansion and retraction of activity, but they cannot offer an accurate assessment of the numbers of local societies since they are limited to those that chose to affiliate to the national Civic Trust. Furthermore, assessing the number of local groups is also complicated by the geographic fragmentation of the movement from the 1960s. Separate Civic Trusts were formed in Wales and Scotland in 1964 and 1967 respectively, and linked organizations emerged in some English regions during the same period. Recently Civic Forums, representing federations of local groups and aiming to extend civic participation, have been established in certain major cities, notably London, Edinburgh and Glasgow. ${ }^{19}$ The English Civic Trust ceased to exist in 2009 and has been superseded since by Civic Voice. ${ }^{20}$ Current numbers of local civic groups remain difficult to assess, but those affiliated to the Scottish 
and Welsh Civic Trusts and to Civic Voice amount to approximately 470 individual societies.

Over the second half of the twentieth century, societies affiliated to the Civic Trust were encouraged to adopt a standard wording for their objectives. ${ }^{21}$ Thus, the constitutions of many local groups refer to a commitment to encourage high standards in architecture and planning, support for the protection of historically or aesthetically significant sites or buildings, and the education of the public in the history, geography and culture of their locality. These broad objectives have provided the foundation for a wide variety of activities rooted in the attempt to extend the involvement of local residents in decision-making and practical action. The major activities of local associations encompass engaging directly and routinely with local planning authorities, campaigning activity in relation to particular sites, running local architectural and heritage award schemes, the purchase of land to prevent or shape development and the ownership and management of local museums or heritage sites. At a smaller scale, activities often include running local heritage walks, researching, writing and publishing local histories, organizing programmes of lectures and visits, and running community engagement programmes, such as tree planting. Organizations functioning at a national and regional level tend to focus on a different range of activities, the most notable often being the organization of conferences and award schemes. However, engagement with political and professional bodies in order to represent the perspective of the movement is also a central aspect of the work of the national bodies and results in the establishment of institutionalized interconnections, such as the All Party Parliamentary Group for Civic Societies, and in government funding and endorsement for award schemes. ${ }^{22}$

In research conducted during the 1970s, civic associations were seen as forming the core of the 'local environmental movement.' ${ }^{23}$ Indeed, Barker and Keating also argued that civic groups '[we]re a notable element of the entire "citizen participation” movement in Britain. ${ }^{24}$ Subsequent trends in local activism, particularly as a reflection of growing concern for environmentalism and sustainability, have meant that civic associations now take their place amongst a much more crowded field of organized activity concerned with place. They have, however, been a significant force over the full period of their existence, not least, and not unproblematically, because they have often been constituted by a membership of professionally qualified, politically literate and networked individuals with high levels of social capital and strong commitment to their sphere of interests. 


\section{Associational activity and the development of planning and conservation}

At the beginning of the twentieth century there was no established system of town planning as such. Some city corporations had had a long history of involvement in significant urban development projects and local government had acquired a regulatory role in the implementation of standards related to basic public health, including the raft of local bye-laws introduced in the latter part of the nineteenth century. However, this kind of activity did not amount to the legislative framework and the more extensive competences vested in local authorities from the early twentieth century, nor did it represent a wider or systematic consideration of the quality of place. The first legislation with planning in the title, 'The Housing, Town Planning, Etc. Act,' was introduced in 1909 and in the same year the first programme of town planning education was created at Liverpool University in the new Department of Civic Design. Together with the foundation of the first dedicated professional body, the Town Planning Institute, in 1914, these landmarks signalled that planning was emerging as the accepted and desirable activity of a distinct and specialised professional group.

Yet, this new professional activity was slow to gain purchase within the sphere of public action and little extensive planning work was undertaken by local authorities until the late interwar period. ${ }^{25}$ Instead, early innovation in planning was often led by voluntary bodies such as the Garden City Association (acting through its First Garden City Limited Company) and the Hampstead Garden Suburb Trust which bequeathed landmark developments at Letchworth and Hampstead respectively. ${ }^{26}$ Alongside these well-known actions, civic groups were also engaged in less well-known planning initiatives. Among the most significant of these was the early work of the London Society, which provided the momentum, the expertise and the funding for a Development Plan for Greater London produced during the First World War. Emerging out of discussions at Britain’s first international Town Planning Conference, held in the capital in 1910, the London Society's project sought to coordinate the activities of local authorities across the Greater London area and in so doing secure an arterial road infrastructure for the conurbation. The Society's members included a number of prominent professionals, including Raymond Unwin, George Pepler and Stanley Adshead, and the Plan was, therefore, the work of early pioneers within the planning profession. ${ }^{27}$ Here the Society was effectively providing a capacity for strategic 
thinking that was absent from local governance. In other cities too, amenity groups were responsible for commissioning or producing early planning reports. Abercrombie’s 1923 report on the planning of Stratford-upon-Avon, for example, was commissioned by the Stratford-upon-Avon Preservation Committee, while the Southampton Civic Society drew on the professional and academic expertise of its members to conduct and publish a study of the town intended to lay the foundations for major town planning work in $1931{ }^{28}$

Ideas about the conservation and regulation of the historic urban environment were similarly developing through the discussions and activities of civic associations. In a 1905 lecture to the Civic Society of Glasgow, Society member John Stirling Maxwell, proposed the formation of a new body in the city that could consider questions of architectural conservation. In a prescient anticipation of what would later emerge in the structure and function of local government, Maxwell argued that a 'building censorship' should have the power

(a) to schedule every monument or building which they considered should be preserved in the public interest, such building not to be altered inside or outside without their sanction: (b) to examine and sanction designs for all such alterations or additions to existing buildings as were visible from the public streets and for all new buildings: (c) to formulate a policy for the widening of streets, the creation of open spaces, and the laying out of new suburbs. ${ }^{29}$

Maxwell continued to pursue his interests through the Civic Society during the 1920s and became a founding member of the National Trust for Scotland in 1931. Over following decades many other local groups established campaigns for similar reasons. The group that commissioned Abercrombie in Stratford upon Avon, for example, was formed in an attempt to resist a factory proposal. Gavin Stamp notes the formation of the Norwich Society in 1923 to resist the demolition of the medieval Bishop's Bridge and their continued efforts to protect the city's historic architecture over the following half century. ${ }^{30}$ Stamp also points to the formation of the Old Plymouth Society in the 1920s as a response to the demolition of sixteenth and seventeenth century houses, followed by the Barbican Association in the same city in 1957 to fight further demolitions. ${ }^{31}$

Civic groups and their members were, therefore, important early promoters of both planning and conservation, and by the interwar period their role in these spheres was well recognised. In 1920 Patrick Abercrombie published a paper in which he advocated the formation of civic groups across the country. Abercrombie framed the sphere of activities of 
such groups by reference to the objectives of the 1909 Planning Act - 'securing proper sanitary conditions, amenity and convenience' - and argued that societies could act 'as a constant referendum' keeping the local authority 'informed of public opinion. ${ }^{32}$ In 1925 Guy Dawber reinforced this in his inaugural address as President of the Royal Institute of British Architects. Dawber used the speech to propose the formation of 'Civic Committees.' His main emphasis lay on encouraging measures that would support conservation, however he seems also to have conceived civic associations as a means of more broadly supporting the development of local place identities through a partially democratic mechanism. 'In certain towns and districts,' he argued, 'there might be formed small Civic Committees, annually elected by the ratepayers, whose duty it would be to try and foster wider interest in their localities, their historic traditions, their romance, and their architecture. ${ }^{33}$ Escalating this rhetoric and the proposed scale of associational activity, and making explicit the lobbying function of the civic movement, Douglas Goldring, one of the founders of the Georgian Group, wrote in 1936,

'There does not at present exist any means of canalising public feeling about these matters in such a way as to make protest really effective... There is therefore urgent need of a central Civic Society, with branches in every borough to give the public advance information whenever the rights of the community are threatened and to organise resistance. ${ }^{34}$

This comment, made two years before the formation of the first national civic group, indicated the growing sense that commitment among local communities to shaping and safeguarding the quality of place needed a vehicle for coordination and representation. Local civic groups continued their active involvement in initiatives to protect monuments, historic buildings and place character. In Bath, for example, the Bath Preservation Trust was one of the promoters of the 1937 Bath Corporation Act, which brought a measure of control over the facades of 1,251 historic buildings in the city. ${ }^{35}$ The Oxford Preservation Trust and the Cambridge Preservation Society both engaged in land purchase to help protect the setting of each city. ${ }^{36}$ Elsewhere, societies undertook early scheduling work, for example, publishing lists of buildings that would later be protected under Town and Country Planning Act, 1947. During the second world war they were instrumental in cities such as Bristol in recording the architectural losses and survivors of war damage, ${ }^{37}$ in sponsoring (for example in the rural district of Sudbury ${ }^{38}$ ) or even directly undertaking planning exercises (for example, the conservation-minded plan for Tunbridge Wells ${ }^{39}$ ), as part of the effusion for planning of this 
period. ${ }^{40}$ Conversely, groups could be a potent oppositional force to such war-time and postwar plans, as Stamp describes for Canterbury. ${ }^{41}$

\section{Modes of participation: association, opposition and local networks}

The powers and responsibilities of local government grew steadily in the first three quarters of the twentieth century and in the process moved local government into a central position in place management. To understand the participative role of civic associations, therefore, we need to understand their evolving interactions with the local state and with the planning system. In her discussion of the formation of the National Trust, Melanie Hall has pointed to the crucial importance of the reform of local government and the creation of new county councils. ${ }^{42}$ As local amenity groups would also do, she has indicated that the newly formed Trust sought to influence local government both by campaigning from without and also from within by encouraging its supporters to seek election to these new authorities and thereby join official decision-making processes. As already indicated, local civic groups pursued a range of different activities, but their modes of participation appear, from existing evidence, to polarise around the contrasting approach of opposition, on the one hand, and interconnected networking, on the other. Their history provides insight, therefore, into the geographically and temporally varied boundaries between state and civil society.

The potential for associations to serve as vehicles for oppositional activity was clearly present from the outset of the civic movement. For example, in Guildford a group was formed in the late 1890s in response to on-going alterations to the town's High Street; their comments here clearly suggest they felt isolated in their views:

\footnotetext{
'A hideous boot shop is now being erected in the High Street...Lower down a saddlers shop is to be rebuilt, opposite to that two fine old plain brick houses are coming down and so on. The Corporation care nothing, the property owners less, save to make big shops, with plate glass fronts, build them as cheaply as possible and make money. ${ }^{43}$
}

Such sentiment became a widespread response to on-going urban transformation. Further, the oppositional stance was connected to growing attempts to establish a basis for resistance to official policies or corporate decisions that seemed remote from the places they affected and careless of the consequences for communities; local civil society offered the organizational resistance to the centralization taking place in political and economic spheres. Thus, Lord 
Esher assured the societies he addressed in announcing the formation of the Central Council of Civic Societies that the first attempt at national organization was based on a recognition of 'local patriotism.' He argued that effective local resistance to national policies required the increased strength of a collective response:

'Civic problems in these days are indissolubly entwined with national. The great trunk roads run through the cities; housing and town-planning are nation-wide in their application. The central government, intent upon its national scheme, ignores local objection and rides roughshod over local sentiment and local patriotism. Unity is required to stand up to the ignorant indifference of distant officials and impersonal capitalist organizations. ${ }^{44}$

Local oppositional activity by civic associations peaked in the 1960s and 1970s as conflict over the imposition of modernist architecture and comprehensive planning by local authorities precipitated a crisis between state and communities. The multiple local conflicts over the future form of place were documented in a series of national and local polemics that often highlighted the role of local groups in opposing public authorities and developer-led schemes, typically encompassing road building, demolition of historic buildings, clearance of housing areas and so on. ${ }^{45}$ Conflict over the fate of particular buildings was common and often resulted in polarised rhetoric that pitted a desire to retain features of the built environment viewed as locally distinctive against commercial expediency and the political drive to 'modernise.' In some high-profile historic cities such as Bath this conflict was so intense that it became a matter of national debate. ${ }^{46}$ Similarly, the fate of a small nonconformist chapel in Worcester became the focus for a local campaign that gained national coverage. Built in the early nineteenth century, by the late 1970s the chapel, which stood adjacent to the city's central shopping area faced demolition so that the site could be used for additional car parking. The city's civic association lead a campaign to save the chapel that resulted in acrimonious confrontations with the City's mayor and eventually gathered support from outside the city, notably from John Betjeman. ${ }^{47}$ The group eventually succeeded in persuading the City Council to sell the building and its site, formed a Buildings Preservation Trust to facilitate fund-raising and redevelopment, and reopening the chapel a decade later as a music school and concert hall for the city. Such cases are typical of the period, indicative of broader shifts in Britain's political culture and of the potentially strong opposition that voluntary associations could mount against the local state. 
In contrast, however, other civic groups, or sometimes the same groups at different points in their history, have had substantial interconnections with their city councils and other influential local bodies suggesting the porosity of boundaries between the state and civil society in some local contexts. Some of the clearest examples can be seen through an assessment of the membership of some early associations. For example, in 1918 the Birmingham Civic Society’s first chairman, George Cadbury Junr., was also the chairman of the City Council's Town Planning Committee while other founding members of the body included his brother, William Cadbury, an alderman and the Lord Mayor, and Neville Chamberlain, MP for the city and the soon to be Minister for Housing. Close interconnections with other major institutions in the city, notably the University of Birmingham, established an influential position for the group who were able to press the Council over matters of concern, securing cooperation through their institutional and political networks. ${ }^{48}$ Membership lists also provide evidence of civic associations representing a considerable concentration of local professional expertise. Notable examples of this kind of concentration can be seen in the early twentieth century when, for example, the London Society drew on a membership of planners that included a majority of the founding committee of the Town Planning Institute and six out of ten of the Institute's first Presidents. ${ }^{49}$ In this context civic groups acted as influential conduits for emergent ideas from significant figures in the nascent planning profession. Figures like Patrick Abercrombie and Raymond Unwin were both members of civic associations and used the meetings of societies to outline their approaches to planning. Abercrombie, a figure who bestrides planning in the first half of the twentieth century, had an enormous influence through his roles as an academic, a prolific consultant, an advisor to government and a proselytiser for planning, and saw civic groups as a means of pressing forward that agenda. ${ }^{50}$ He also emphasised the importance of a professional and well connected membership, recommending particular care be taken over the membership of the executive committee:

\footnotetext{
'The Executive Committee is the very lantern of the Society...[it] should have a certain number of members of the great constructive professions; Engineers, Architects, Surveyors and Town Planners, Doctors and Sociologists, are equally essential; for the remainder it would be advisable to have business men. ${ }^{, 51}$
} 
Developing strong local networks was, therefore, a key part of the work of civic associations and explicitly advocated as a strategy by certain early promoters of the movement.

Furthermore, there are indications that such networks remained characteristic of the movement in the later twentieth century. The example of Warwick suggests their presence in the mid-twentieth century, while in research conducted in the 1970s, Lowe examined the extensive networks utilised by civic groups and explicitly conceived local associations as strategic actors in the political negotiation over how urban space is used. ${ }^{52}$ He also pointed out that the forms of political action which civic groups engaged in was grounded in their ability to claim and deploy professional expertise:

'They [local civic societies] make representations through the accepted channels; their instinct is against such tactics as demonstrations and direct action. They seek to employ, and to stress the value of, expert local knowledge, and professional planning and architectural skills in formulating their response to development proposals. ${ }^{, 53}$

This description distances civic associations from the direct political action characteristic of the period and places them as part of the less examined elite civil society of twentieth century Britain. Further, a survey of associations in Yorkshire in the early 1970s used by Lowe found that 74 per cent of groups in urban areas could draw on the skills of members representing at least six different professions and regularly extended to include architects, historians, lawyers, planners, surveyors, journalists, archaeologists and teachers. ${ }^{54}$ Similar findings emerged in the late 1990s from the Civic Trust's own survey into 'The Relationship between Civic Societies and Local Authorities.' This showed that a majority of associations could call on professional advice from architects, planners, surveyors and other professionals within their membership and that 63 per cent of associations which operated in areas where a Conservation Areas Advisory Committee existed were represented on that Committee, thus indicating that in many urban areas civic associations were directly involved in governance through their participation in such local structures. ${ }^{55}$ What this also helps to illustrate is that civic groups have had different performative roles. Part of the claim for influence of embedded groups, using a "responsible style," ${ }^{56}$ is that they bring an expertise and capacity to the local state and its decision-making that may not exist within the organisation. In practice this may be a cover for advancing a particular sectional interest (see, for example, the analysis of the Barnsbury area of Islington, London in the $1970 \mathrm{~s}^{57}$ ). Alternatively, groups 
may be more straightforwardly exerting their "voice” as part of a participative democratic process.

\section{Participation and urban governance in historical perspective}

As the preceding discussions demonstrate, over the twentieth century civic groups were seeking and negotiating ways to participate in decision-making about the quality and development of place. Variable practices of local participation were, therefore, evolving in advance of the high profile discussions about community involvement that emerged in the late 1960s. The role of local associations were, nevertheless, affected by those debates and became more publicly and explicitly formulated as a result. The context for this re-framing was the important and widespread debate about the nature of representative democracy. In particular, the social movements that came into focus during the 1960s and 1970s questioned the 'civic deference' that had arguably dominated Britain's political culture for the earlier portion of the century, challenged the sufficiency of existing means of participation and encouraged many to engage in more direct and confrontational political action. ${ }^{58}$ As these critiques were articulated, and as experience of comprehensive planning shattered the optimism promulgated by the post-war planners, the privileged place of the professional planner also came under scrutiny. ${ }^{59}$ This was, then, a period in which the relationship between the state and civil society was actively questioned and it was this context that added fuel to the discussions of participation in planning and conservation activities that were occurring at the time. When it was published, in 1969, the Skeffington Report made direct reference to these wider debates:

\footnotetext{
'It may be that the evolution of the structures of representative government which has concerned western nations for the last century and a half is now entering into a new phase. There is a growing demand by many groups for more opportunity to contribute and for more say in the working out of policies which affect people not merely at election time, but continuously as proposals are being hammered out and, certainly, as they are being implemented. ${ }^{60}$
} 
The newly formed national Civic Trust sought to press forward and cement the place of civic associations in local governance as public and political concern with participation increased. In a 1967 paper on 'Citizen Participation and Decision Making in Town Planning' the then director of the Civic Trust, Leslie Lane, suggested that developers, authorities and 'the people' were the 'three parties involved in town planning and development' and that the contemporary challenge was 'to provide for a real degree of interplay between these forces. ${ }^{61}$ He identified key points for discussion arising out of this recognition, among them the propositions that 'local authorities should actively support local civic societies' and that 'a continuous relationship between the two should be fostered. ${ }^{62}$ The question of participation remained a core issue for the movement in the years immediately following, with the Civic Trust conference held in York in 1968 focusing on the participation of amenity societies in planning following the passing of the Town and Country Planning Act, 1968, and a Ditchley conference on 'Public Participation in Urban Planning' held in association with the Trust in 1969. The Trust continued to emphasise the value of interconnection between political and civil spheres. At the 1968 conference, for example, Duncan Sandys ${ }^{63}$ argued that

'The character and status of civic societies and their relationship with local authorities has completely altered. Now the Government and Parliament are actively inviting independent amenity organizations to take part in the planning process. Even closer co-operation in this field is going to develop. ${ }^{64}$

Underlining the value of overlapping memberships in local governance, he continued

'There would be advantages if some members of these societies were to try to get themselves elected on to their local council, just as there would be advantages if more local Councillors joined their local civic societies. ${ }^{65}$

This characterisation and positioning of civic associations as representatives of local interests and directly engaged in urban governance directly echoes pronouncements made by Abercrombie and Dawber earlier in the century. Furthermore, there was cross-party impetus to this agenda. Labour MP Niall MacDermot, for example, attended the 1968 Civic Trust conference in York and spoke of the potentially augmented role that local societies could play under the provisions for public participation made by the 1968 Act: 
'The new Act w[ill] give new opportunities and responsibilities to amenity societies which they ha[ve] not enjoyed up to now. The real test of democracy is the extent to which it gives people an opportunity to take part in making decisions which affect them.' 66

In addition, the reforms of the 1960s effectively recognised the different formal performative roles civic groups may play in local decision-making. For example, in introducing Conservation Area Advisory Committees in 1968 the Government explicitly acknowledged the lack of historic environment expertise in most local authorities at that time; the role of committees and their membership was in part to compensate for this deficit. ${ }^{67}$ The landmark Skeffington Report, however, was more about extending the democratic mandate into wider participative planning processes, an agenda that has remained potent ever since through to the current rhetorical emphasis on localism.

In order to maximise their influence it is perhaps not surprising that groups may blur together these roles. A well educated and networked membership of professionals allows groups to claim their views as authoritative and at the same time civic groups have frequently sought to position themselves as representing wider public opinion. For example, Law's work on civic groups in York and Leeds highlighted how groups in these cities regarded themselves as figures of authority but concurrently utilized an anti-elitist discourse as part of their self-construction as 'the voice of the people'. ${ }^{68}$ To further their legitimacy, these groups positioned themselves as morally virtuous, with an emotional appeal to pride in place and local patriotism. This is the projection of a disinterested commitment to good planning and design, concealing any sectional interest that may be being promoted. Indeed, as the pressure to engage in participative approaches grew in the 1970s, it often suited local authorities to work with civic groups to fulfil this commitment as a relatively fixed identifiable point and able to communicate using the same technical language and concepts used in the planning process ${ }^{69}$. However, echoing Abercrombie's emphasis on the importance of the executive group, Coxall has argued that amenity bodies are often constituted to avoid the active participation of their own membership in decision-making. ${ }^{70}$ In practical terms, decisions are taken by small executive groups, with little or no reference, or explicitly excluding, the participation of the wider membership.

Thus, the repeated conflation of civic groups with the more general 'public' is problematic and connects with current debates about participation and deliberative planning 
processes. Within the renewed emphasis on community, there has been a growing recognition of the need to scrutinise the nature of 'community' groups and the power relations that exist both within and between them. Jones, for example, has argued that 'there has been a glaring neglect of... power relations and participation as political and social discourse and practice. ${ }^{, 71}$ While in their recent study Brownill and Carpenter discuss an example of participative planning in Oxford in which a deliberative process of engagement faltered as the input of certain community groups 'revealed the tensions and power differentials within the community. ${ }^{72}$ In the Oxford case this was highlighted by a cyclists group:

'Consisting mainly of white middle-class men...the cyclist lobby were technically literate with some of them being transport professionals in their "day jobs.” The difference in skills and the fact that both the cyclists and the design team could use technical language helped exclude "ordinary” community members present at the Design Days. ${ }^{73}$

Clearly, the local networks and high levels of 'in-house' professional expertise discussed in the previous section of the paper suggests that civic associations may possess the potential to deploy similar tactics. As we seek to understand the past and the present of local community involvement in place-making and management such knowledge brings the important recognition that local groups have variable professional, social and political resources that establish differences in their abilities to engage effectively in processes of urban governance. Indeed, in relation to civic organizations this point was raised in the 1970s by Lowe, who argued that

'The evident effectiveness of one type of local environmental pressure group with a particular social composition, largely professional and managerial middle class, highlights the disparity of political influence, technical skills, and organizational resources between amenity societies and other local environmental interest groups, such as tenants' associations, not so well endowed with competence and contacts. ${ }^{, 74}$

This argument is an important one for evaluating participation and aligns with other findings that deal with resident and environmental groups and with public service provision more generally. $^{75}$

In historical perspective, however, this mode of relating to local authorities might be understood as a continuation of the patterns of interaction and engagement central to urban 
culture since the Victorian period and even before. It is well-established that modern urban culture has been marked by the dominance of networked local elites. Konishi's detailed research on eighteenth-century King's Lynn, for example, emphasised the prevalence of 'collaborative relationships' among local elites and concluded by arguing that 'the various public spheres were neither completely separated nor opposed to each other...the urban elite could be active in multifarious spheres and could perform their role as leaders without confrontation. ${ }^{76}$ This pattern continued during the nineteenth century when urban governance was configured around the interactions between local government and local voluntary agencies, with both dominated by an interconnected middle class and local elite. ${ }^{77}$ And, indeed, one of the primary recognitions of historians interested in urban governance is the permeability of the boundaries between state and civil society. ${ }^{78}$ However, far less research considers the continuation of these patterns into the urban culture of the twentieth century. The growth of the welfare state and the private sector certainly represented significant structural change, which brought concomitant alterations to urban life, yet based on the evidence discussed here, there is cause to argue that, in relation to the management of place through planning and conservation policy, the centrality of a local public culture dominated by dense interconnections between state and civil society has continued to be a powerful force in urban governance. Thus, while historical research has shown 'the long middle-class retreat from urban public life' in certain important respects, ${ }^{79}$ the rise of policy processes based on professional discourses and technical literacy also offered new ground on which to sustain patterns of alliance and exchange that have a much longer lineage.

\section{Conclusions}

A century or more of disparate local group activities necessarily suggests a marked diversity of experience in different places and different periods. This has included civic group engagement in the advocacy of processes of both change and continuity and collaboration with and opposition to local governance networks. Cumulatively, this has been an important influence in the formation of policies and practices and over decisions and actions that have shaped place in twentieth century urban Britain. Civic bodies have been a significant part of the local public sphere and significant in terms of patterns of participation in individual places. Set against this are inevitable questions of representativeness; local groups can make 
an important and seemingly relevant contribution to their locality, but how should we regard them in the democratic process? Precisely whose values are being represented?

Urban associational cultures are dynamic and heterogeneous and the experiences and positioning of individual local amenity groups have varied considerably over time. Indeed, the existence of one local group has provided no bar to the formation of another, so in some contexts new groups have been formed to oppose change in spite of the presence of already extant local bodies. York 2000, for example, was formed in the early 1970s to fight innerring road proposals despite the existence of the active and well-established York Civic Trust (founded in 1946), because the latter was felt to be too close to the Council and too compliant in its approach. ${ }^{80}$ This long history of co-operation and conflict, of participation but of limited representativeness has significant potential to contribute to contemporary debates about participatory practice. As new planning schemas seek to generate "bottom-up”, citizenled planning processes, there will be an inevitable reoccurrence of the questions we have raised here; whose "voice” should count and who, in a complex urban area, (other than elected politicians) can legitimately claim to represent public opinion? Furthermore, the current move to localism, accompanied as it is by austerity budgets and the retrenchment of the local state, asks questions about quite what the role of local groups in this process is supposed to be? Political rhetoric has emphasised an extension of the democratic process, extending participation into a more systemic engagement as part of a deliberative democratic process. However, alternatively one could see the phase we are now in as a historical reversion. As the state retreats, the role of civic groups and other bodies becomes essential in providing capacities and expertise that have historically accumulated in local authorities.

We have used a review of available evidence relating to the history of civic organizations to make three key points. First, we wish to emphasise the importance of Britain's voluntary culture in the development of processes of planning and conservation, particularly during the first half of the twentieth century. Amenity groups acted as a conduit for ideas and gave momentum to innovations in practice. However, second, it is also clear that from an early stage associations have engaged in complex negotiations over their relationship with local authorities. We have pointed to the dual role that groups have played as both collaborators in a networked and often elite local urban public sphere and as campaigning groups opposing policy and practice in sustained and sometimes successful ways. In both modes associations were participating in decision-making, and this offers useful evidence to extend understandings of the historical development of participation. Third, in our closing section we concentrated on examining the discussions surrounding 
debates about community participation that emerged in the late 1960s and sought to use these and our earlier discussions to engage with the difficulties inherent in such processes. On the one hand, the 1960s might seem to represent the key period when the dominant mode of operation of local groups shifted from co-operation to a more combative approach, as groups became more separate from local decision-making elites and as challenges to authority became stronger across society. However, on the other hand, it is clear that local voluntary groups with reserves of professional expertise and the associated social and cultural capital have greater ability to participate in a field that became increasingly dominated by technical knowledge and legislative control throughout the twentieth century. This is likely to resonate into the localist processes and practices now being advocated. From an historical perspective, therefore, this sphere of voluntary activity suggests continuities with longer term practice, rather than the paradigm shifts that are sometimes described in accounts of the development of participation.

\section{Acknowledgements}

We would like to thank the reviewers for helpful and constructive comments.

\section{Funding}

The review has been conducted as part of a scoping study supported by the Arts and Humanities Research Council (AHRC) under the Connected Communities programme [AH/J012106/1]

\footnotetext{
Notes

${ }^{1}$ The local associations which provide the focus for discussion in this paper exists across the UK. However, within the UK there are complex governance arrangements, made more so by the recent devolution of power to the Scottish Government and Welsh Assembly, meaning that some of the statutes and policies referred to are sometimes specifically English. Though discussions of localism have perhaps been most visible in England, where the Localism Act took effect in late 2011, there are comparable initiatives in other parts of the UK. In Scotland, for example, a programme of community asset transfer has been underway since 2009 with the explicit intention of developing increased in civic pride and community empowerment through local participation in place.

${ }^{2}$ See Cherry, The Evolution of British Town Planning; Cullingworth and Nadin, Town and Country Planning; Sandercock, 'The democratization of planning.'

${ }^{3}$ Cooke and Kothari, Participation: The New Tyranny?; Agger, 'Towards tailor-made participation.'

${ }^{4}$ Brownill and Carpenter, 'Participation and planning.'

${ }^{5}$ See Special Issue of Planning Perspectives on 'Participation and the Modernization Process,' ed. Sebastian Haumann, 26 (2011) no. 1.

${ }^{6}$ Haumann, 'Editorial.'

${ }^{7}$ Clark, British Clubs and Societies.
} 
${ }^{8}$ The concept of Conservation Area Advisory Committees was introduced by central government in 1968 in the Ministry of Housing and Local Government Circular 61/68. The intention was that '... local planning authorities should establish conservation area advisory committees, including persons not members of the authority, and refer to them for advice applications which would, in the opinion of the authority, affect the character or appearance of the conservation area. The work of these advisory committees need not be confined to questions arising on applications for planning permission or listed building consent. They could also play a useful part in the general care and maintenance of conservation areas and in making positive proposals for their enhancement.'

${ }^{9}$ For example, for American local associations see Duncan and Duncan, Landscapes of Privilege; for case studies of urban governance in Canada, France and India, see contributions to Morris and Trainor, Urban Governance.

${ }^{10}$ Petts and Brooks 'Expert conceptualisations of the role of lay knowledge in environmental decisionmaking'

${ }^{11}$ See most obviously texts based around recent political administrations, for example, Allmendinger 'Urban Planning and the British New Right' 'New Labour and Planning', Punter 'Urban Design and the British Urban Renaissance', Thornley 'Urban Planning Under Thatcherism'. Other histories, however, often stress discontinuities and change (for example, Taylor 'Urban Planning Theory since 1945') or are focused on very particular periods (for example, Hasegawa 'Replanning the Blitzed City Centre'. This is not to deny the scholarship and the contribution provided by any of these texts but that an emphasis on periodization, and discontinuities between periods, can underplay important continuities in planning and participation.

12 Jokilehto, A History of Architectural Conservation; Cherry, The Evolution of British Town Planning.

${ }^{13}$ Levine, The Amateur and the Professional; Briggs, Victorian Cities; Anderson and Darling, 'The Hill Sisters.'

${ }^{14}$ Cities Committee, Report of a conference of civic societies organized by the Cities Committee of the Sociology Society, (1923) Foundations of British Sociology Archive, Keele University, reference GB172 LP/1/4/2/5; Esher, 'A New Plan.'

${ }^{15}$ Hewitt, 'Associational culture and the shaping of place.

${ }^{16}$ The Civic Trust aimed both to support local civic societies and to act in its own right in lobbying over the quality of new buildings and public spaces and the conservation of historic environments.

${ }^{17}$ Barker and Keating, 'Public Spirits'.

${ }^{18}$ Larkham, Conservation and the City.

19 See London Civic Forum (2010) Review of the role and remit of London Civic Forum http://www.londoncivicforum.org.uk/wordpress/wpcontent/uploads/downloads/2011/04/Review-ofthe-role-and-remit-of-London-Civic-Forum-August-2010.pdf (accessed 1 August 2012); Glasgow Civic Forum (2012) Glasgow Civic Forum Remit, http://www.scottishcivictrust.org.uk/civic-trustnetwork/glasgow-civic-forum.aspx (accessed 2 August 2012).

${ }^{20}$ Civic Voice has similar aims to the Civic Trust, although operates on a somewhat smaller scale.

${ }^{21} \mathrm{P}$. D. Lowe, 'Amenity and equity: a review of local environmental pressure groups in

Britain,' Environment and Planning A, 9, no 1 (1977) p 40.

${ }^{22}$ See Civic Voice (2011) ‘All Party Parliamentary Group for Civic Societies,'

http://www.civicvoice.org.uk/about/all-party-parliamentary-group-appg-for-civic-societies/ (accessed, 3 August 2012); Scottish Civic Trust (2012) 'My Place Awards 2012,'

http://www.myplaceawards.org.uk/news/my-place-awards-2012.aspx (accessed 3 August 2012).

${ }^{23}$ Barker and Keating, 'Public Spirits'; Lowe, 'Amenity and Equity.'

${ }^{24}$ Barker and Keating, 'Public Spirits', p 144.

${ }^{25}$ See early commentary on progress under the 1909 Act see Abercrombie, 'The Town Planning Act,' p 57; also Ward, Planning and Urban Change.

${ }^{26}$ See Buder, Visionaries and Planners; Hall, Cities of Tomorrow.

${ }^{27}$ Beaufoy, “'Order out of chaos”'; Hewitt, 'Towards a greater urban geography'.

${ }^{28}$ Abercrombie and Abercrombie, Stratford-upon-Avon; Ford Southampton: A Civic Survey. 
${ }^{29}$ John Stirling Maxwell, 'Censorship of Buildings in Cities' (1905) Mitchell Library Archives, Glasgow, T-PM122/4/21.

${ }^{30}$ Stamp, Britain's Lost Cities.

${ }^{31}$ Stamp, Britain's Lost Cities, p 167.

${ }^{32}$ Abercrombie, 'A civic society,' p 80 \& 83.

${ }^{33}$ Dawber, 'The Inaugural Address,'p 6.

${ }^{34}$ Quoted by Burton, 'A Cuckoo in the Nest,' p 246.

${ }^{35}$ Pendlebury, 'The Modern historic city', p 255.

${ }^{36}$ Ward, Planning and Urban Change, 53; Cooper, Planners and Preservationists.

${ }^{37}$ A list of 'Buildings in Bristol of Architectural or Historic Interest damaged or destroyed by Enemy Action, 1940-42,' was prepared under the auspices of the Council for the Preservation of Ancient Bristol and later published in the Transactions of the Bristol and Gloucestershire Archaeological Society, vol. 65, 1944.

${ }^{38}$ Jeremiah, A Full Life in the Country.

${ }^{39}$ Spalding, Tunbridge Wells: A Report, p 82.

${ }^{40}$ See, for example, Larkham, 'The place of urban conservation'; Larkham and Lilley Planning the 'City of Tomorrow'.

${ }^{41}$ Stamp, Britain's Lost Cities.

${ }^{42}$ Hall, 'The Politics of Collecting'.

${ }^{43}$ Letter from George C. Williamson, founder of the Guildford Society, to Thackeray Turner, secretary of the Society for the Protection of Ancient Buildings, $3^{\text {rd }}$ October 1896. SPAB archives.

${ }^{44}$ Esher, 'A New Plan to Save Our Cities,' p 118.

${ }^{45}$ Such as Aldous, Battle for the Environment; Heighway, The Erosion of History; Coard and Coard, Vanishing Bath; Fergusson, The Sack of Bath; Aldous, Goodbye Britain?; Amery and Cruikshank, The Rape of Britain; Cormack, Heritage in Danger.

${ }^{46}$ See, for example, Architectural Review, 'Bath: City in Extremis'; Coard and Coard Vanishing

Bath; Fergusson The Sack of Bath.

47 'A chapel in danger,' The Times, 13 June 1977.

${ }^{48}$ Haywood, The Work of the Birmingham Civic Society, (Birmingham, 1946); Hewitt, 'Associational culture and the shaping of place,' pp 601 \& 603.

${ }^{49}$ Hewitt, 'Towards a greater urban geography.'

${ }^{50}$ Abercrombie, 'A Civic Society.'

${ }^{51}$ Abercrombie, 'A Civic Society,' p 90.

${ }^{52}$ Hewitt, 'Associational culture and the shaping of place,' p 598-599; Lowe, 'Amenity and Equity.'

${ }^{53}$ Lowe, 'Amenity and Equity,’ p 40.

${ }^{54}$ Lowe and Goyder, Environmental Groups in Politics, p 41.

${ }^{55}$ National Council of Civic Trust Societies, The Relationship between Civic Societies and Local Authorities, 12-13.

${ }^{56}$ Lowe and Goyder, Environmental Groups in Politics.

${ }^{57}$ See Lowe 'Amenity and Equity'

${ }^{58}$ Black, Redefining British Politics, pp 8-9.

${ }^{59}$ Pendlebury, Conservation in the Age of Consensus, pp 64-67;

${ }^{60}$ Committee on Public Participation, People and Planning, p 3.

${ }^{61}$ Lane, 'Citizen Participation.'

${ }^{62}$ Lane, 'Citizen Participation.'

${ }^{63}$ Sandys was the founder of the Civic Trust whilst a Conservative government minister and was generally a well-known supporter of the civic and conservation movement.

${ }_{64}$ Duncan Sandys, Open Address to the York Conference of Amenity Societies, 27-29 September, 1968, Conference Report, Civic Trust Archives: p 2.

${ }^{65}$ Duncan Sandys, Open Address to the York Conference of Amenity Societies, 27-29 September, 1968, Conference Report, Civic Trust Archives: p 2.

66 Niall MacDermot, 'The Planning Process,' York Conference of Amenity Societies, 27-29 September, 1968, Conference Report, Civic Trust Archives: p 3. 
67 Jordan et. al 'Participation and Conservation'

${ }^{68}$ Law, 'The Built Heritage Conservation Movement,' p 385.

${ }^{69}$ Lowe and Goyder, Environmental Groups in Politics.

${ }^{70}$ Coxall, Pressure Groups in British Politics.

${ }^{71}$ Jones, ‘Urban Regeneration's Poisoned Chalice', p 583. See also Campbell, 'The darker side of local communities.'

${ }^{72}$ Brownill and Carpenter, 'Participation and planning,' p 420.

${ }^{73}$ Brownill and Carpenter, 'Participation and planning,' p 420.

${ }^{74}$ Lowe, 'Amenity and Equity,' p 42.

${ }^{75}$ See Short, Fleming and Witt, Housebuilding, Planning and Community Action. Similar concerns also emerged from a recent review of evidence relating to middle classes and public service provision. Hastings and Matthews point out that middle class individuals are more likely to associate -join groups - in order to pursue their concerns, more likely to possess a range of knowledge and skills 'cultural capital' - that enable them to negotiate with public authorities and policy processes more effectively, and, crucially, that this capital 'corresponds with the value set of bureaucrats with power and influence' leading to a circumstance in which 'there is the potential for an alliance to develop between middle class service providers and users.' Hastings and Matthews, Connectivity and Conflict.

${ }^{76}$ Konishi, 'Elite and pluralist power,' p 17.

${ }^{77}$ Morris and Trainor, Urban Governance.

${ }^{78}$ Morris, 'Governance,' pp 1-2.

${ }^{79}$ Shapely, 'Planning, housing and participation,' p 77.

${ }^{80}$ See Cummin York 2000; Palliser, 'Preserving our heritage'; John Pendlebury, Conservation in the Age of Consensus.

\section{Bibliography}

Abercrombie, Patrick. 'The Town Planning Act. Memorandum of Progress and New Procedure Regulations.' Town Planning Review, 5, no 1 (1914): 57-63.

Abercrombie, Patrick. 'A civic society. An outline of its scope, formation and functions.' Town Planning Review, 8, no 2 (1920): 79-92.

Abercrombie, Patrick and Lascelles Abercrombie, Stratford-upon-Avon: Report on Future Development, prepared at the instance of the Startford-upon-Avon Preservation Committee. London: Hodder and Stoughton, 1923.

Aldous, T. Battle for the Environment. London: Fontana, 1972 .

Aldous, T. Goodbye Britain? London: Sidgwick and Jackson, 1975.

Allmendinger, P. and H. Thomas, Eds. Urban Planning and the British New Right. London, Routledge, 1998

Allmendinger, P. New Labour and Planning: From New Right to New Left. London, Routledge, 2011. Amery, C. and D. Cruikshank. The Rape of Britain. London: P. Klek, 1975.

Anderson, Anne and Elizabeth Darling. 'The Hill Sisters: Cultural Philanthropy and the Embellishment of Lives in late Nineteenth Century England.' In Women and the Making of Built Space in England, 1870-1950, edited by Elizabeth Darling and LesleyWhitworth, Aldershot: Ashgate, 2007.

Annika Agger. 'Towards tailor-made participation: how to involve different types of citizens in participatory governance.' Town Planning Review, 83 (2012) 29-45.

Architectural Review. 'Bath: City in Extremis.' Architectural Review 153 (915): 280-306.

Barker, A. and M. Keating. 'Public Spirits: Amenity Societies and Others.' In Participation in Politics, edited by Colin Crouch, London: Croom Helm, 1977.

Beaufoy, Helena. “'Order out of chaos”: the London Society and the planning of London, 1912-1920.’ Planning Perspectives, 12, no.2 (1997): 135-164.

Black, Lawrence. Redefining British Politics: Culture, Consumerism and Participation, 1954-1970. Basingstoke, Hampshire: Palgrave Macmillan, 2010. 
Briggs, Asa. Victorian Cities. London: Penguin, 1968.

Brownill, Sue and Juilet Carpenter. 'Participation and planning: dichotomies, rationalities and strategies for power.' Town Planning Review, 78 (2007) 401-428.

Buder, Stanley. Visionaries and Planners: The Garden City Movement and the Modern Community. Oxford: Oxford University Press, 1990.

Burton, Neil. 'A Cuckoo in the Nest: The Emergence of The Georgian Group.' In From William Morris: Building Conservation and the Arts and Crafts Cult of Authenticity, edited by Chris Miele. New Haven and London: Yale University Press, 2005.

Campbell, Heather. 'The darker side of local communities: Is this the Real World of planning?’ Planning Theory and Practice, 6, no. 4 (2005) 517-19.

Cherry, Gordon E. The Evolution of British Town Planning: A History of Town Planning in the United Kingdom During the Twentieth Century and of the Royal Town Planning Institute. Leighton Buzzard: Leonard Hill, 1974.

Clark, P. British Clubs and Societies, 1580-1800. Oxford, 2000.

Coard, P. and Coard, R. Vanishing Bath. Bath, Kingsmead Press, 1973.

Committee on Public Participation in Planning. People and Planning. London: HMSO, 1969.

Cooke, Bill and Uma Kothari. Participation: The New Tyranny? London: Zed Books, 2001.

Cooper, Anthony J. Planners and Preservationists: The Cambridge Preservation Society and the City's Green Belt 1929-1985. Cambridge: Cambridge Preservation Society, 2000.

Council for the Preservation of Ancient Bristol. 'Buildings in Bristol of Architectural or Historic Interest damaged or destroyed by Enemy Action, 1940-42.' Transactions of the Bristol and Gloucestershire Archaeological Society, 65, 167-174, 1944.

Cormack, P. Heritage in Danger. London, Quartet Books, 1976.

Coxall, B. Pressure Groups in British Politics. Harlow: Longman, 2001.

Cullingworth, Barry and Vincent Nadin. Town and Country Planning in the UK, $13^{\text {th }}$ edition. London and New York: Routledge, 2002.

Cummin, D, ed. York 2000: People in Protest. York: York 2000.

Dawber, Guy. 'The Inaugural Address,' Journal of the Royal Institute of British Architects, 33 (1925) 1-7.

Duncan, James S. and Nancy G. Duncan. Landscapes of Privilege: The Politics of the Aesthetic in an American Suburb. New York and London: Routledge, 2004.

Esher, Viscount. 'A New Plan to Save Our Cities.' The Journal of the London Society, 258 (1939): 118-119.

Fergusson, A. The Sack of Bath. Salisbury: Compton Russell., 1973.

Ford, P, ed. Southampton: A Civic Survey. Being a report of the Civic Survey Committee of the Southampton Civic Society. Oxford: Oxford University Press, 1931.

Hall, Melanie. 'The Politics of Collecting: The Early Aspirations of the National Trust, 18831913.' Transactions of the Royal Historical Society, 13 (2003) 345-57.

Hall, Peter. Cities of Tomorrow: An Intellectual History of Urban Planning and Design in theTwentieth Century. Oxford: Blackwell, 2002.

Hasegawa, J. Replanning the Blitzed City Centre: a comparative study of Bristol, Coventry and Southampton 1941-1950. Buckingham, OUP, 1992

Hastings, Annette and P. Matthews. Connectivity and Conflict in Periods of Austerity: What so we know about Middle Class Participation and Activism and its Effects on Public Services? Project Report, AHRC/Connected Communities, 2011. Accessed $3^{\text {rd }}$ March 2013. doi: $\quad$ http://www.ahrc.ac.uk/Funding-Opportunities/Research-funding/ConnectedCommunities/Scoping-studies-andreviews/Documents/Connectivity\%20and\%20conflict\%20in\%20periods\%20of\%20austerity.p df

Haumann, Sebastian. 'Editorial. Participation and the modernization process.' Planning Perspectives, 26 no. 1, (2011): 1-2.

Haywood, William. The Work of the Birmingham Civic Society. Birmingham, 1946.

Heighway, C. M, eds. The Erosion of History: Archaeology and Planning in Towns. London, Council for British Archaeology, 1972. 
Hewitt, Lucy E. 'Towards a greater urban geography: regional planning and associational networks in London during the early twentieth century.' Planning Perspectives, 26 (2011) 4, 551-568.

Hewitt, Lucy E. 'Associational culture and the shaping of place: civic societies in Britain before 1960.' Urban History, 39, no 4 (2012) 590-606.

Jeremiah, K. A Full Life in the Country: The Sudbury \& District Survey \& Plan. London, Batsford, 1949.

Jokilehto, Jukka. A History of Architectural Conservation, Oxford: Butterworth-Heineman, 1999.

Jones, Peris S. 'Urban Regeneration's Poisoned Chalice: Is There an Impasse in (Community Participation-based Policy?’ Urban Studies, 40, no 3 (2003), 581-601.

Jordan, A. G., R. H. Kimber, J. J. Richardson. 'Participation and Conservation: The Chester Conservation Area Advisory Committee.’ Local Government Studies 1 no 4 (1975): 1-11.

Konishi, Emi. 'Elite and pluralist power in eighteenth-century English towns: A case study of King's Lynn.' In Who Ran the Cities? City Elites and Urban Power Structures in Europe and North America, 1750-1940, edited by Ralf Roth and Robert Beachy, Aldershot: Ashgate, 2007.

Lane, Leslie, 'Citizen Participation and Decision Making in Town Planning.' Civic Trust Archives, March 1967.

Law, A. 'The Built Heritage Conservation Movement: landscapes of Englishness and social class.' Phd diss.,_University of Newcastle, 2004.

Larkham, Peter J. Conservation and the City, London and New York: Routledge, 1996.

Larkham, Peter J. "The place of urban conservation in the UK reconstruction plans of 19421952." Planning Perspectives 18, no.3 (2003): 295-324.

Larkham, Peter J. and K. Lilley. Planning the 'City of Tomorrow', British reconstruction planning, 1939-1952: an annotated bibliography. Pickering, North Yorkshire, Inch's Books, 2001.

Levine, Philippa. The Amateur and the Professional: Antiquarians, Historians and Archaeologists in Victorian England, 1828-1886. Cambridge: Cambridge University Press, 2002.

Lowe, P. D. 'Amenity and equity: a review of local environmental pressure groups in Britain.' Environment and Planning A, 9, no 1 (1977) 35-58.

Lowe, P. and J. Goyder. Environmental Groups in Politics. London, George Allen \& Unwin, 1983.

Morris, R. J. and Richard H. Trainor, eds. Urban Governance. Britain and Beyond since 1750, Aldershot: Ashgate, 2000.

Morris, R. J. 'Governance: two centuries of urban growth.’ In Urban Governance. Britain and Beyond since 1750, edited by R. J. Morris and Richard H. Trainor. Aldershot: Ashgate, 2000.

National Council of Civic Trust Societies, The Relationship between Civic Societies and Local Authorities, Civic Trust, 1998.

Palliser, D. M. 'Preserving our heritage: the historic city of York.' In Campaigning for the Environment edited by R. Kimber and J. J. Richardson. London: Routledge and Kegan Paul, 1974.

Pendlebury, John. 'The Modern historic city: Evolving ideas in mid-20 ${ }^{\text {th }}$-century Britain.' Journal of Urban Design, 10, no. 2 (2005): 253-273.

Pendlebury, John. Conservation in the Age of Consensus, London: Routledge, 2009.

Petts, J. and C. Brooks 'Expert conceptualisations of the role of lay knowledge in environmental decisionmaking: challenges for deliberative democracy.' Environment and Planning A 38 no 6 (2006): 1045-1059.

Punter, J., Ed. Urban Design and the British Urban Renaissance. Abingdon, Routledge, 2010

Sandercock, Leonie. 'The democratization of planning: elusive or illusory?' Planning Theory and Practice, 6, no 4. (2005) 437-441. 
Shapely, Peter. 'Planning, housing and participation in Britain, 1968-1976,' Planning \# Perspectives, 26, no. 1 (2011): 75-90.

Short, John R., Stephen Fleming and Stephen J. G. Witt. Housebuilding, Planning and Community Action: the Production and Negotiation of the Built Environment. London: Routledge and Kegan Paul, 1986.

Spalding, H. Tunbridge Wells: A Report presented at the request of the Borough Council. Tunbridge Wells, The Tunbridge Wells Civic Association, 1945.

Stamp, Gavin. Britain's Lost Cities. A Chronicle of Architectural Destruction. London, Aurum Press, 2007.

Taylor, N..Urban Planning Theory since 1945. London, Sage, 1998.

Thornley, A. Urban Planning under Thatcherism: the Challenge of the Market. London. London, Routledge, 1991.

Ward, Stephen V. Planning and Urban Change. London: Sage, 2004. 